Revista Eletrônica Geografar, Curitiba, v. 2, Resumos do VI Seminário Interno de Pós-Graduação em Geografia, p. 10-10. Junho/2007

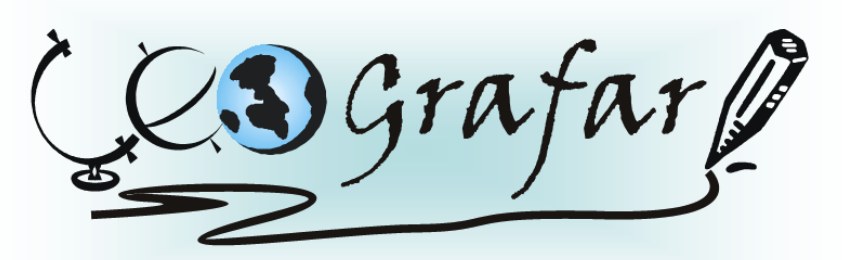

Revista Eletrônica do Programa de Pós-Graduação em Geografia - UFPR

\title{
REPRESENTAÇÕES SOCIAIS DA ESCASSEZ E POLUIÇÃO DAS ÁGUAS
}

\author{
BEATRIZ FAGUNDES ${ }^{1}$
}

Esta pesquisa tem por objetivo desvendar e interpretar as representações sociais que os moradores dos Bairros, Santana e Alto da XV, em Guarapuava, têm em relação à escassez da água e a poluição e canalização dos rios urbanos decorrentes do processo de urbanização. Os referidos bairros localizam-se numa sub-bacia hidrográfica constituída por rios que nascem no perímetro urbano da cidade de Guarapuava formando o Arroio Salgado. Por estarem hoje na malha urbana, as suas áreas naturais se encontram degradadas. A problemática que as cidades tendem a destruir os ambientes naturais e a poluir as suas águas, causando riscos à qualidade e quantidade da água potável e outros tipos de água, tem sido cada vez mais objeto de estudo da rede científica. A passagem destes conhecimentos do debate científico ao senso comum dá, junto com outros conhecimentos especializados como religiosos e saberes específicos populares, conformação às representações sociais sobre este assunto no meio urbano. Neste sentido, a teoria das Representações Sociais, desenvolvida na psicologia social por Serge Moscovici, é utilizada para pesquisar as motivações de comportamento e atitudes ambientais dos moradores embutidos nas suas relações sociais. Trata-se de uma teoria que pesquisa os indivíduos e suas formas de pensamento a partir do senso comum, envolvidos em processos de comunicação no cotidiano. Assim, espera-se compreender como representações são capazes de gerar condutas sociais, tanto na preservação como na agressão ao meio ambiente. Acreditamos que um trabalho como o nosso pode subsidiar possíveis ações de educação ambiental no meio urbano a serem desenvolvidas na comunidade e nas escolas para oferecer uma melhor qualidade de vida para a população.

Palavras-chave: Representação social, ambiente urbano, escassez da água, poluição, rios urbanos.

'Mestranda em Geografia - UFPR - email: beafagundes@yahoo.com.br Orientador: WOLF DIETRICH-SAHR 